\title{
Muziek en natievorming in België: het muziekleven te Brussel, 1830-1850
}

\author{
KOEN BuYens
}

\section{Inleiding}

Hoe overleven kleine landen? ${ }^{2}$ In België werd getwijfeld aan de levensvatbaarheid van de nieuwe staat. Het land was klein, maar dichtbevolkt en had een hoge graad van verstedelijking bereikt. Op het gebied van grondstoffen was het verre van misdeeld en de vooruitstrevende economische politiek sinds de tweede helft van de achttiende eeuw had gunstige voorwaarden geschapen voor een efficiënte exploitatie en snelle industrialisering. En toch was er twijfel. Kon België wel aanspraak maken op de onontbeerlijke zelfstandigheid als staatkundige entiteit? In zijn politieke geschiedenis was niet die mate van continuiteit te bespeuren die België's bestaan en voortbestaan voor andere landen tot een niet ter discussie te stellen evidentie makten. Tot de ondertekening van de XXIV artikelen in 1839 was België een speelbal geweest in het politieke pokerspel tussen de Europese grootmachten en het zou tot 1848 duren, het revolutiejaar dat de Belgische regering met succes wist te bezweren, vooraleer diezelfde grootmachten bereid waren het land een vorm van politieke volwassenheid toe te kennen. ${ }^{3}$ Voor het nieuwe regime kwam het er dus op aan België een gezicht te

1 Dit artikel is de uitgewerkte versie van een lezing gehouden op de lentevergadering van de Koninklijke Zuid-Nederlandse Maatschappij voor taal, letterkunde en geschiedenis (Brussel, 19 maart 2005) en is gebaseerd op het tweede deel van mijn proefschrift, dat ik op 27 mei 2004 aan de Vrije Universiteit Brussel verdedigde, onder de titel 'Van de krekel en de mier. Het muziekleven te Brussel, 1750-1850'. Dank ben ik verschuldigd aan prof. H. Soly voor de waardevolle opmerkingen en aan prof. E. Witte voor de literatuursuggesties. In de tekst wordt regelmatig verwezen naar artikels in de krant L'Indépendant / L'Indépendance Belge. De auteurs van deze artikels ondertekenden met hun initiaal of een ander letterteken. Slechts in enkele gevallen kon de naam van de auteur achterhaald worden (X. X. = Edouard Fétis; E. R. = Eugène Robin). Voor de gevallen waarin de auteur onbekend is, wordt in voetnoot vóór de titel van het artikel het gebruikte initiaal of letterteken aangegeven. Met betrekking tot de archivalia worden de volgende afkortingen gebruikt: ARA/ Cons. = Algemeen Rijksarchief Brussel, Fonds Koninklijk Muziekconservatorium Brussel en $\mathrm{SAB} / \mathrm{OO}=$ Stadsarchief Brussel, Fonds van Openbaar Onderwijs, Schone Kunsten en Openbare Feestelijkheden.

2 C. A. Tamse, Nederland en Belgie in Europa (1859-1871). De zelfstandigheidspolitiek van twee kleine staten (Den Haag, 1973).

3 R. Coolsaet, België en zijn buitenlandse politiek 1830-2000 (Leuven, 2001) 19-106; E. Witte, 'De doorbraak van een burgerlijke parlementair-constitutionele staat (1830-1848)', in: E. Witte, J. Craeybeckx, A. Meynen, Politieke geschiedenis van Belgie van 1830 tot heden (Brussel, 1997) 2730 en $54-57$. 
geven. Het besef was daarbij aanwezig dat Willem I, die zoveel gerealiseerd had in het economische domein, tekortgeschoten was in het voeren van een nationale cultuurpolitiek. ${ }^{4}$ Belgie mocht niet in dezelfde fout vervallen en diende de vorming en consolidatie van het land tot een hecht natieverband op planmatige, beredeneerde wijze ter harte te nemen. ${ }^{5}$

Tot de bouwstenen waar de overheid in dit natieproject op kon terugvallen, behoorde ook de muziek. De muziek kreeg in het proces van natievorming zelfs een bijzondere plaats. Het collectief musiceren, gaande van de wekelijkse oefenstonde van de plaatselijke blaaskapel tot de groots opgezette nationale muziekfestivals, was als geen andere cultuuruiting in staat te bezielen en te mobiliseren. ${ }^{6}$ Naast het bevorderen van de interne cohesie en saamhorigheid had de muziek een niet te verwaarlozen aandeel in 's lands prestigepolitiek. De centrale plaats van opera en concerten in het leven van de Europese (hoofd) stedelijke elites en de groeiende rol in dat van de middengroepen maakten van de belangrijkste muziekinstellingen nationale visitekaartjes, terwijl muzikale sterren en virtuozen in het buitenland optraden als culturele ambassadeurs van hun vaderland. ${ }^{7}$

Dit artikel behandelt het muziekleven te Brussel in zijn relatie met de Belgische natievorming. Eerst wordt scherpgesteld op de figuur van FrançoisJoseph Fétis, die de muzikale wederopbouw van België en zijn hoofdstad ter hand nam. Het tweede onderdeel belicht het belang van de militaire component

4 Op de geringe belangstelling van Willem I voor de schone kunsten is reeds gewezen in studies over de beeldende kunsten, waarmee de koning overigens iets meer affiniteit had dan met de muziek.Zie C. Loir, L'émergence des beaux-arts en Belgique. Institutions, artistes, public et patrimoine (1772$1835)$ (Brussel, 2004); E. Bergvelt, 'Koning Willem I als verzamelaar, opdrachtgever en weldoener van de Noordnederlandse musea', in: C. A. Tamse, E. Witte, ed., Staats-en natievorming in Willem I's koninkrijk (1815-1830) (Brussel, Baarn, 1992) 261-285; E. Koolhaas-Grosfeld, 'Nationale versus goede smaak. Bevordering van nationale kunst in Nederland: 1780-1840', Tijdschrift voor geschiedenis, XCV (1982) 605-636, in het bijzonder 623.

5 Els Witte heeft het in dit opzicht over 'competente bouwers van de natiestaat'; zie E. Witte, 'De constructie van België, 1828-1847', in: E. Witte, e. a., Nieuwe geschiedenis van België, I,1830-1905 (Tielt, 2005) 194-212 en 221-223. Over de natie en nationale identiteit als 'constructies' van politieke elites, zie T. de Meester, 'De exclusieve natiestaat. Pleidooi voor een constructivistische benadering van nationalisme en nationale identiteit', Belgisch tijdschrift voor nieuwste geschiedenis, XXVII (1997) 473-547.

6 Vergelijk H. W. von der Dunk, De verdwijnende hemel. Over de cultuur van Europa in de twintigste eeuw, I (Amsterdam, 2000) 43-45; B. Glaner, 'Nationalhymnen', Die Musik in Geschichte und Gegenwart. Allgemeine Enzyklopädie der Musik. Sachteil (MGG Sachteil), VII (Kassel, 1997) 19; F. G. Eyck, The voice of nations. European national anthems and their authors (Londen, 1995) xiii-xx; S. Dubois, 'De symbolen van de Belgische Staat', in: S. Dubois, J. Janssen, A. Minke, De Belgische vertoning. Symbolen-rituelen-mythen (Brussel, 2005) 39-48 en 96 (literatuuroverzicht).

7 Zie E. Fétis, 'Chronique musicale ... Les artistes belges à l'étranger', L'Indépendant (1 mei 1841). 
in het Brusselse muziekleven. In het derde onderdeel wordt het problematische karakter van de Belgische natievorming als cultuurproject - het politiekcultureel dualisme en de culturele afhankelijkheid van Frankrijk - in de beschouwing betrokken.

\section{François-Joseph Fétis en de muzikale (weder)opbouw van België}

Een hoofdrol in de muzikale Gestaltung van België speelde François-Joseph Fétis (1784-1871), die in 1833 aan het hoofd van het Brusselse conservatorium kwam te staan. De uit Bergen afkomstige Fétis was toen reeds geruime tijd één van de gezaghebbende muzikale stemmen in Parijs, waar hij als leraar compositie verbonden was aan het vermaarde conservatorium. Fétis genoot echter in de eerste plaats Europese faam als muziekcriticus en -wetenschapper. ${ }^{8}$ Nadat burggraaf Charles Hippolyte Vilain XIIII ${ }^{9}$, voorzitter van de bestuurscommissie van het Brusselse conservatorium, Fétis daartoe had uitgenodigd, zette deze zich aan de redactie van een lijvig Plan d'organisation de la musique dans le Royaume de Belgique. ${ }^{10}$ In dit document formuleerde hij nauwgezet de voorwaarden waaraan het jonge koninkrijk moest voldoen, wilde het in Europa muzikaal opnieuw meetellen. Een grote inspanning was nodig, want het muziekleven in België bevond zich volgens hem in een onmiskenbare "état de dépérissement."

8 Zie A. van der Linden, 'Les premiers candidats à la direction du Conservatoire de musique de Bruxelles', Belgisch tijdschrift voor muziekwetenschap (BTM), V (1951) 36-37; Verslag aan minister van binnenlandse zaken Charles Rogier, 15 juni 1833 - ARA/Cons. 10. Zie voor François-Joseph Fétis: R. Wangermée, François-Joseph Fétis. Musicologue et compositeur. Contribution à l'étude du goût musical au XIXe siècle (Brussel, 1951); François-Joseph Fétis en het muziekleven van zijn tijd, 1784-1871 (Brussel, 1972; met een samenvattende bibliografie van de musicologische geschriften); J. Eeckeloo, 'François-Joseph Fétis: musicoloog, conservatoriumdirecteur, componist en verzamelaar in één persoon', in: L. P. Grijp, ed., Een muziekgeschiedenis der Nederlanden (Amsterdam, 2001) 417-422; BTM, XXVI-XXVII (1972-1973) bevat diverse aan Fétis gewijde artikels. Zie voor een vollediger literatuuropgave R. Wangermée, 'Fétis, FrançoisJoseph', Die Musik in Geschichte und Gegenwart. Allgemeine Enzyklopädie der Musik. Personenteil (MGG. Personenteil), VI (Kassel, 2001) 1087-1095; K. Ellis, R. Wangermée, 'François-Joseph Fétis', The New Grove Dictionary of music and musicians (NGD), VIII (Londen, 2001) 746-749.

9 T. Juste, Le vicomte Charles Vilain XIIII, ministre d'Etat, ancien membre du Congrès national et ancien ministre des affaires étrangères (Brussel, 1875) behandelt uitsluitend het politieke leven van Vilain XIIII en laat zijn rol in de geschiedenis van het conservatorium onvermeld. Zie verder P. de Wilde, Een beknopte geschiedenis van de familie Vilain XIIII (Kruibeke, 1996).

10 Plan Fétis, 10 oktober 1832 - ARA/Cons. 10. Het plan telt negentien handgeschreven bladzijden. In de kanttekening staat vermeld dat het om een kopie van de hand van Vilain XIIII gaat. Een licht afwijkende versie van het plan is als bijlage terug te vinden in Wangermée, François-Joseph Fétis, 288-299 (met als bronvermelding: Annuaire du Conservatoire royal de musique de Bruxelles ([Brussel], 1884) 178201).

11 Wangermée, François-Joseph Fétis, 290. 
Om dit om te buigen drong Fétis aan op een muzikale machtsconcentratie in zijn persoon.

Ecoles, théâtres, fêtes musicales, concerts, tout doit être reglé par un système unique, organisé par un homme habile et protégé par le gouvernement. C'est à ces conditions que le génie des Belges pour l'art musical se développera de nouveau,

betoogde hij. ${ }^{12}$ Wat de leiding van het conservatorium betreft, dat in de muzikale wederopstanding van het land een speerpuntfunctie te vervullen had, achtte hij het noodzakelijk dat hij als directeur met een onbeperkt gezag - 'une autorité sans bornes' - bekleed zou worden. ${ }^{13}$

Fétis' Plan d'organisation belicht zijn nogal autoritaire karakter, maar wegens de denkschema's en attitudes, die eraan ten grondslag liggen, is het document ook relevant voor de mentale structuur van de bredere samenleving waar hij deel van uitmaakte. Uit de tekst spreekt vooral een krachtig voluntarisme. België's muzikale wedergeboorte was geen kwestie van geduldig afwachten. Het was daarentegen een 'project' in de sfeer van het maatschappelijk maakbare, onder voorwaarde welteverstaan dat de realisatie ervan werd toevertrouwd aan een uitzonderlijk individu. In die zin beantwoordde Fétis, als een muzikale redder des vaderlands, aan het romantische genie-concept, en het geniale school niet enkel in een visionaire geest, maar evenzeer in grensverleggende daadkracht.

De heroïsche rol waarin de Belgische regering Fétis, en Fétis vooral zichzelf zag, paste in een tijdsgewricht waarin het vormen van nationale mythen als een dringende noodzaak ervaren werd. Bij nader inzien beantwoorden deze mythen aan een vast, dialectisch schema, met in den beginne een even zuivere als krachtige oerstaat waarna de natie, in een antithetisch moment, door invloeden van buitenaf - vreemde overheersing en verdrukking - in een crisis belandt. ${ }^{14}$ Omdat naties in dit discours als vaste, natuur-gegeven entiteiten beschouwd worden, zijn ze per definitie onsterfelijk. ${ }^{15}$ Maar om uit de als sluimerend of zelfs comateus te omschrijven toestand te ontwaken, is de interventie nodig van één of een kleine schare 'grote mannen', die haar uiteindelijk, op het moment van synthese, boven zichzelf weten uit te tillen en op definitieve wijze in de vaart der volkeren doen opnemen. In dit schema van de nationale mythe komt het erop aan de toestand van verval even donker voor te stellen als de wederopstanding spectaculair. Hoe groter de discrepantie tussen beide momenten, des te krachtiger

12 Ibidem, 289.

13 De woorden 'autorité sans bornes' werden gebruikt in het handgeschreven document. In de versie van Wangermée is sprake van een 'autorité absolue'; zie Ibidem, 295.

14 Met betrekking tot België, zie J. Stengers, 'Le mythe des dominations étrangères dans l'historiographie belge', Belgisch tijdschrift voor filologie en geschiedenis, LIX (1981) 383-401.

15 De gedachte van de natie als natuur-gegeven komt reeds mooi tot uiting in de aanhef van Fétis' plan, waar hij stelt: 'L'organisation physique et morale des Belges est favorable à la musique et généralement à la culture des arts'; zie Wangermée, François-Joseph Fétis, 288. 
getuigt de natie van haar onverwoestbare levensenergie, wat vervolgens weer afstraalt op de helden die in de wederopstanding het voortouw namen.

In het verhaal van België's muzikale herstel zijn deze ingrediënten gemakkelijk aan te wijzen. Door zijn grondige kennis van de muziekgeschiedenis had Fétis reeds een helder besef van de uitzonderlijke rijkdom die in de kunst van de Nederlandse polyfonisten uit de Renaissance gelegen was. In hoeverre de musici uit dit gouden tijdperk als 'Belgen' te kwalificeren zijn, zoals Fétis doet, is natuurlijk een andere kwestie. Richt men de blik op het tweede element in de mythe - de tijd van verval - , dan blijkt het verhaal zoals dat na 1830 vorm kreeg, een stuk problematischer. In zijn plan zette Fétis de dramatische gevolgen van de Franse annexatie in 1795 voor het muziekleven adequaat uiteen, maar de tijd die eraan voorafging, in het bijzonder de regeerperiode van Maria Theresia (1740-1780), werd door hem duidelijk ondergewaardeerd. Aan het hof van Karel van Lotharingen, die door de keizerin als gouverneur-generaal naar Brussel was afgevaardigd, ontwikkelde zich een belangwekkende muzikale activiteit. Toch is die onderwaardering Fétis nauwelijks aan te rekenen, aangezien deze muziek pas in tweede helft van de twintigste eeuw opnieuw in de belangstelling is gekomen. ${ }^{16}$ Echt geweld deed Fétis de geschiedenis aan in zijn beoordeling van het Nederlandse bewind. Graag erkende hij de verdiensten van Willem I voor de economie, maar wat betreft de muziek was zijn oordeel kort en bondig:

Il faut rendre justice au Prince qui gouverna ce pays pendant seize ans: l'industrie fut protégée et acquit du développement; la peinture reçut aussi des encouragements; mais le Roi n’aimait pas la musique, il ne fit rien pour elle. ${ }^{17}$

Dat de muziek Willem, de koning-koopman, niet bijzonder na aan het hart lag, kan nauwelijks verbazen, maar daaruit volgt niet automatisch dat hij voor de bevordering van het muziekleven in zijn koninkrijk niets zou hebben ondernomen. Meer bepaald de oprichting, bij Koninklijk Besluit van 9 juni 1826, van vier Koninklijke Muziekscholen - twee in het Noorden (Amsterdam, Den Haag) en twee in het Zuiden (Brussel, Luik) - , zou de ontwikkeling van de muziekcultuur in Nederland en België, ook na 1830, duurzaam beïnvloeden. Met deze maatregel wilde de koning vooral voorkomen dat de katholieke kerk de

16 S. Clercx, 'L'épanouissement au XVIIIe siècle', in: E. Closson, C. van den Borren, ed., La musique en Belgique du moyen âge à nos jours (Brussel, 1950) 201-233; M. Couvreur, ed., Le théâtre de la Monnaie au XVIIIe siècle (Brussel, 1996); Idem, ed., Musique et spectacles à Bruxelles au XVIIIe siècle (Etudes sur le XVIIIe siècle,XIX) (Brussel, 1992); F. de Haas, I. Smets, ed., Mozart in België. Een wonderkind op reis in de Zuidelijke Nederlanden, 1763-1766 (Antwerpen, 1990); R. Wangermée, P. Mercier, ed., La musique en Wallonie et à Bruxelles, I, Des origines au XVIIIe siècle (Brussel, 1980) 201-425.

17 Wangermée, François-Joseph Fétis, 289. Fétis voegt er nog aan toe dat de Muntschouwburg, anders dan in het onafhankelijke België, financieel ten laste van de centrale overheid gevallen was, maar, 'livré à des mains inhabiles', had het theater daar geen enkel voordeel uit weten te trekken. 
opleiding van musici naar zich toe zou trekken, zoals dat tijdens het ancien régime in belangrijke mate het geval geweest was. Vanuit een muzikaal standpunt is Willems extra-muzikale motivatie echter weinig relevant. De nieuwe scholen waren een feit en de muziek kon er slechts wel bij varen. ${ }^{18}$

Toen de Belgische regering in 1832 besloot een Conservatoire royal in Brussel op te richten, ging het dus om de voortzetting van een bestaande instelling en niet om een creatio ex nibilo. ${ }^{19}$ In de samenstelling van het lerarenkorps was de continuïteit groot. ${ }^{20}$ Wel had het de Koninklijke Muziekschool aan een krachtige leiding ontbroken. De bestuurscommissie, die vijf door de minister van binnenlandse zaken benoemde leden telde, was namelijk niet overgegaan tot het aanstellen van een directeur. Zij had zich ertoe beperkt een beroep te doen op aanvankelijk twee en sinds 1829 drie inspecteurs die hun functie zonder vergoeding uitoefenden en weinig impact hadden op het onderwijs. ${ }^{21}$ Met de komst van Fétis in 1833 brak er wat betreft de leiding van de instelling inderdaad een nieuw tijdperk aan, maar of de toestand van het Brusselse muziekonderwijs

18 Voor Brussel zie H. Baeck-Schilders, '1826. De bevordering van het muziekonderwijs in Nederland en België', in: Grijp, ed., Een muziekgeschiedenis, 398-402; H. Vanhulst, 'L'enseignement de la musique', in: R. Wangermée, P. Mercier, ed., La musique en Wallonie et à Bruxelles,II, Les XIXe et XXe siècles (Brussel, 1982) 198-200; E. Mailly, Les origines du Conservatoire royal de musique de Bruxelles (Brussel, 1879). Voor Luik, en met informatie over de algemene ontstaansgeschiedenis van de vier muziekscholen, zie J. Quitin, 'L'intervention du gouvernement hollandais dans la création du Conservatoire Royal de Musique de Liège en 1826', in: A. Smijers, ed., Société Internationale de Musicologie. Cinquième Congrès (Utrecht 3-7 juillet 1952). Compte Rendu (Amsterdam, 1953) 327-334. Voor de vier muziekscholen werd van overheidswege een bedrag van in totaal 30.000 florijnen uitgetrokken. Jeroen van Gessel wijst erop dat geen enkel Europees land, Frankrijk uitgezonderd, het op dit punt beter deed. Opnieuw een argument om Fétis' bewering dat Willem I niets deed voor de muziek, te nuanceren; zie J. van Gessel, 'Een vaderland van goede muziek. Een halve eeuw Maatschappij tot bevordering der toonkunst (1829-1879) en het Nederlandse muziekleven' (niet uitgegeven proefschrift Universiteit Utrecht, 2001) 62.

19 Ook uit de naamsverandering - 'Conservatoire' in de plaats van 'Ecole de musique' — valt geen substantiële promotie van de instelling af te leiden. Zij weerspiegelt slechts de Parijse situatie. Zie J. Mongrédien, La musique en France des Lumières au Romantisme (1789-1830) (Parijs, 1975) 26-27.

20 Na de Revolutie van 1830 werden slechts twee muziekleraars van de Koninklijke Muziekschool ontslagen. Al was de continuïteit groot, toch dient men er rekening mee te houden dat het lerarenkorps na 1832 snel uitbreidde. Zie Etat nominatif et détaillé de l'Ecole de musique de Bruxelles, 30 september 1830 - SAB/OO I/95; Almanach Royal Officiel, publié en exécution d'un arrêté du Roi, par Tarlier. Neuvième année: 1850 (Brussel, 1850) 427-428; alsook Mailly, Les origines, 106-118; H. Vanhulst, 'Le Conservatoire royal de musique de Bruxelles. Origine et directorat de FrançoisJoseph Fétis (1833-1871)', in: A. Bongrain, Y. Gérard, ed., Le conservatoire de Paris, 1795-1995. Des Menus-Plaisirs à la Cité de la musique (Parijs, 1996) 201-217.

21 Als inspecteurs fungeerden Charles Louis Hanssens sr. (dirigent Muntschouwburg), Corneille van der Plancken (dirigent en violist) en, sinds juni 1829, Ch. Spaak (aanvoerder tweede violen Muntschouwburg). Zie E. Mailly, Les origines, 30-31, 36-37, 51-52, 66-67 en 84. 
en muziekleven onder Willem I even belabberd was als hij in zijn Plan d'organisation liet doorschemeren, is twijfelachtig.

Om zijn eigen verdiensten in het licht te stellen, had Fétis er natuurlijk alle belang bij de muzikale stand van zaken bij zijn aantreden zo donker mogelijk voor te stellen. Zo kon hij zijn bereidheid om Parijs voor Brussel te ruilen inkleden als een uit idealisme gedragen offer voor het vaderland. ${ }^{22}$ Het eigen aandeel van Fétis in de mythevorming rond de Belgische muzikale wederopstanding was aanzienlijk, en hij liet niet na zijn eigen protagonistenrol in dit proces flink uit de verf te laten komen. ${ }^{23}$ Dat gebeurde onder meer via het nieuws uit de muziekwereld in L'Indépendant (sinds juli 1843 L'Indépendance Belge). ${ }^{24}$ Fétis' oudste zoon Edouard (1812-1906) ${ }^{25}$ was in 1837 toegetreden tot de redactie van dit dicht bij het regime aanleunende Brusselse dagblad, en in de chroniques musicales van zijn hand die ongeveer om de twee weken verschenen, liet hij zich kennen als de spreekbuis van zijn vader. ${ }^{26}$ Telkens wanneer de conservatoriumdirecteur en diens muzikale prestaties besproken werden, hield Edouard zich afzijdig, maar in dat geval werd de lof van François-Joseph Fétis met evenveel overgave gezongen door de collega-redacteur van dienst.

Een vaste aanleiding daartoe waren de conservatoriumconcerten, die Fétis sinds 1833, naar het Parijse voorbeeld, een viertal keer per jaar organiseerde en waarbij hij zelf het orkest van zijn instelling dirigeerde. De opzet van deze concerten was in hoofdzaak pedagogisch. ${ }^{27}$ Fétis wilde het Brusselse publiek langs deze weg inwijden in het grote repertoire, zoals zich dat sinds het laatste kwart van de achttiende eeuw in Europa was gaan uitkristalliseren. Haydn en Mozart stonden op het programma, maar vooral Beethoven, wiens oeuvre, met de negen symfonieën als harde kern, op bijzondere wijze appelleerde aan de

22 Brief van Fétis aan Vilain XIIII, Parijs, 13 oktober 1832 - ARA Cons. 10.

23 F. J. Fétis, 'Fétis (François-Joseph)', in: Biographie universelle des musiciens et bibliographie générale de la musique (8 dln.; Parijs, 1860-1865) III, 235. Brief Fétis, 13 oktober 1832 - ARA/ Cons. 10.

24 A. Vermeersch, 'De structuur van de Belgische pers 1830-1848', in: A. Vermeersch, H. Wouters, Bijdragen tot de geschiedenis van de Belgische pers 1830-1848 (Leuven, Parijs, 1958) 73-81; E. Witte, De 'Moniteur Belge', de regering en het parlement tijdens het unionisme (1831-1845) (Brussel, 1985) 20-26.

25 L. Solvay, Notice sur Edouard Fétis (Brussel, 1922); M. van Kalck, e. a., De Koninklijke Musea voor schone Kunsten van België. Twee eeuwen geschiedenis (2 dln.; Brussel, 2003) passim.

26 Dat wist ook Hector Berlioz, wiens verhouding met de conservatieve Fétis volledig verzuurd was. Zie P. Citron, ed., H. Berlioz, Correspondance générale, III, 1832-1842 (Parijs, 1975) 17; E. Fétis, 'Chronique musicale. Les concerts de M. Hector Berlioz', L'Indépendant (22 oktober 1842); A.van der Linden, 'En marge du centième anniversaire de la mort d'Hector Berlioz (8 mars 1869)', Mededelingen van de Klasse der schone kunsten - Koninklijke Academie van Belgïe, LI (1969) 3675.

27 H. Vanhulst, 'Orchestres et concerts' in: Wangermée, Mercier, ed., La musique,II, 45-47; Wangermée, François-Joseph Fétis, 104-112. 
aspiraties en idealen van de negentiende-eeuwse burgerij. In de muziekkronieken van L'Indépendant werd dit muzikale missioneringswerk van Fétis meermaals gelauwerd. Toen de krant in 1843 de balans opmaakte van zijn tienjarig bewind aan het roer van het conservatorium, luidde de conclusie dat de Brusselaars het aan Fétis te danken hadden dat de muziek van Mozart, Beethoven en Mendelssohn ze inmiddels vertrouwd in de oren klonk. En ze hadden dit alléén aan hem te danken: '[T]out cela a été l'ouvrage d'un seul homme. ${ }^{\text {,28 }}$

Wat de muziek van Beethoven betreft, was die bewering in ieder geval niet juist. In de Nederlandse tijd hadden lokale muziekverenigingen al meermaals orkestmuziek van Beethoven op het programma gezet en ook de kamermuziek was niet helemaal onbekend. Op 1 november 1825 had Brussel kennis gemaakt met nog een ander facet van Beethovens kunst, toen de Société de la Loyauté een Franse versie bracht van het oratorium Christus am Ölberge. ${ }^{29}$ Voor een groot deel waren deze uitvoeringen het werk van de uit Gent afkomstige dirigent en componist Charles-Louis Hanssens (1777-1852), die onder Willem I was opgeklommen tot de post van chef-dirigent in de Muntschouwburg en die zich in 1828 bovendien 's konings kapelmeester mocht noemen. In datzelfde jaar werd zijn neef en naamgenoot, Charles-Louis Hanssens jr. (1802-1871), benoemd tot leraar harmonie en compositie aan de kort tevoren opgerichte Koninklijke Muziekschool, waar zijn oom op dat moment reeds als inspecteur fungeerde. In 1830 stond voor beide musici dus veel op het spel, wat ze in het revolutionaire tumult, weinig verwonderlijk, partij voor Oranje deed kiezen. Met de vestiging van het nieuwe regime verdwenen zij noodgedwongen naar de achtergrond, maar niet voor lang. Hanssens sr. slaagde er al in 1834 in opnieuw leiding te geven aan het orkest in de Muntschouwburg. Dertien jaar later, in 1847, gaf hij de scepter door aan zijn neef. Bij de leiding van of het onderwijs aan het conservatorium zijn zij evenwel nooit betrokken geweest, net zoals Fétis zijn hele leven een buitenstaander is gebleven in de Muntschouwburg. ${ }^{30}$

L. M., 'Concours du Conservatoire de Bruxelles, et grand concours de composition musicale', L'Indépendance Belge (17 augustus 1843).

29 Charles van den Borren gaf 1817 aan als jaartal waarin de naam Beethoven voor het eerst in een Brussels concertprogramma vermeld werd; zie C. van den Borren, 'Les premières exécutions d'oeuvres de Beethoven à Bruxelles', Revue musicale, VIII (1927) 98. Sandrine van Zuylen van Nyevelt heeft inmiddels aangetoond dat reeds op 13 april 1810, nog in de Franse tijd dus, een 'ouverture nouvelle' van Beethoven in Brussel heeft geklonken; zie S. van Zuylen van Nyevelt, 'La vie musicale à Bruxelles. Les concerts vocaux et instrumentaux (1789-1833)' (niet uitgegeven licentiaatsverhandeling Université Libre de Bruxelles, 1986) 40.

30 C. Ballman, 'Hanssens, Charles-Louis-Joseph, gen.l'âné' en 'Hanssens, Charles-Louis (Joseph), gen. le jeune’, MGG. Personenteil, VIII (Kassel, 2002) 676-677; J. Lade, 'Charles-Louis (-Joseph) Hanssens [l'aîné]' en 'Charles-Louis Hanssens', NGD, X, 835-836; L. Bärwolf, Charles-Louis Hanssens. Sa vie et ses oeuvres (Brussel, 1894); Mailly, Les origines, passim. 
Zo tekenden zich in het Brusselse muziekleven twee invloedssferen af. Dit was zeker het geval, nadat Hanssens jr. in 1846 de Association des artistes musiciens had opgericht. ${ }^{31}$ Met deze vereniging bracht Hanssens concerten, die qua programma veel gelijkenis vertoonden met die van Fétis in het conservatorium en waarvan de inkomsten ten goede kwamen aan een pensioenkas voor bejaarde musici. Het symfonische werk van Beethoven stond ook hier centraal, maar Hanssens toonde zich gevoeliger voor nieuwe geluiden, met name uit de Duitse cultuursfeer. Hij was het die voor het Brusselse publiek op 17 februari 1849 de eerste integrale uitvoering van Beethovens Negende verzorgde - de monumentale koorfinale bleef de conservatieve Fétis zijn leven lang een doorn in het oog - en met zijn uitvoering van de Tannhäuser-ouverture op 10 december 1853 weerklonk voor het eerst muziek van Wagner in het land. ${ }^{32}$

Mag men afgaan op een bericht in L'Argus van 22 november 1849, dan kon Fétis het succes van zijn jongere kunstbroeder maar moeilijk verkroppen. De begeleidende spotprent, met als onderschrift 'Le Grrrand Fétis assistant aux concerts de l'Association des artistes musiciens', toont een grimmige oude man met verkrampt gelaat. In zijn rechterhand houdt hij vier gifslangen omkneld. Andere wriemelen hem rond het hoofd en het grootste exemplaar komt onder zijn opzichtig gedecoreerde jas uit gekropen. ${ }^{33}$ Maar dit beeld is wellicht overtrokken. ${ }^{34}$ In zijn geschriften heeft Fétis niet de behoefte gevoeld Hanssens' talent en verwezenlijkingen te miskennen. ${ }^{35}$ Afgezien daarvan waren de twee mannen wel genoodzaakt in de kleine wereld van het muzikale Brussel een modus vivendi te vinden, bijvoorbeeld als leden van de klasse voor Schone Kunsten, die in 1845, op instigatie van Adolphe Quetelet, aan de Koninklijke Academie was toegevoegd. ${ }^{36}$

31 Bärwolf, Charles-Louis Hanssens, 252-256 en 271-272.

32 Reeds in 1850 had Hanssens jr. met het plan rondgelopen om in de Muntschouwburg Wagners Lohengrin op de planken te brengen, maar hij vond te veel obstakels op zijn weg; zie K. Wauters, Wagner en Vlaanderen 1844-1914 (Gent, 1983) 28-30. Fétis, van zijn kant, ontpopte zich tot een strijdbaar anti-wagneriaan; zie N. S. Josephson, 'François-Fétis and Richard Wagner', BTM, XXVI-XXVII (1972-1973) 84-89. Over de vroege receptie van het oeuvre van Wagner in Brussel, zie verder E. Gubin, R. van der Hoeven, 'Les premières manifestations wagnériennes à Bruxelles' en H. Vanhulst, 'Les sociétés de concerts bruxelloises et Wagner (1853-1883)', in: M. Couvreur, ed., La Monnaie wagnérienne (Brussel, 1998) 1-23 en 25-39.

33 Gereproduceerd in François-Joseph Fétis en het muziekleven van zijn tijd, 74.

34 Voor een beoordeling van de verhouding tussen Fétis en Hanssens jr. is het genoemde boek van Bärwolf een nuttig instrument. Zie Bärwolf, Charles-Louis Hanssens, 33-34, 41-42, 49, 53, 127, 252-256 en 271-272.

35 F. J. Fétis, 'Hanssens (Charles-Louis)', in: Biographie universelle, IV, 223-224.

36 J. Lavalleye, L'Académie Royale des sciences, des lettres et des beaux-arts de Belgique 1772-1972. Esquisse historique (Brussel, 1973) 58-59 en 62-63. Fétis bekleedde in de Koninklijke Academie een vooraanstaande positie. Vijf maal nam hij het directeurschap van de Klasse voor schone kunsten waar (1846, 1849, 1855, 1859 en 1868) en tweemaal was hij algemeen voorzitter van de 


\section{Een militaire grondtoon}

Uit Fétis' Plan d'organisation blijkt een gedreven voluntarisme als sleutelelement in zijn mentale dispositie. Zoals gesteld appelleert dit voluntaristische gegeven aan het romantische genie-begrip. De 'grote man' voelt zich als een demiurg geroepen tot het stellen van uitzonderlijke daden die de natie als collectief ten goede komen. Gaat het echter om de uitvoering van het meesterplan, dan is er van vrijheid of creativiteit, laat staan improvisatie, geen sprake meer. Zij stoelt daarentegen op hiërarchie en strakke organisatie. ${ }^{37}$ In dit samengaan van visionaire kracht en autoriteit ziet men Fétis de gedaante aannemen van een muzikale generaal, waarvoor, stilzwijgend, de titanische gestalte van Napoleon model lijkt te staan. In de persoon van de keizerlegeraanvoerder was een bevlogen leiderschap immers een volmaakt huwelijk aangegaan met de eisen van efficiëntie en instrumentalisme die de oorlogvoering en het staatsbestuur in hun moderne verschijningsvorm stelden. ${ }^{38}$

Wie het Brusselse muziekleven sinds de Franse tijd bestudeert, ontwaart spoedig hoe in deze samenleving een militaire grondtoon opklonk. Terwijl tijdens het ancien régime de kerkmuziek alom tegenwoordig was geweest, drong na 1789 de militaire muziek naar voren als het primaire muzikale geluid. Hiervoor zijn verschillende oorzaken aan te wijzen. In het revolutionaire en napoleontische tijdvak verkeerde Europa gedurende meer dan twee decennia in een bijna permanente staat van oorlog. Daarnaast gaf het op de voorgrond treden van de 'natie' in het proces van politieke legitimering aan het leger een geheel nieuwe taak. In plaats van een machtsinstrument in handen van een absoluut monarch, diende het leger in de nieuwe politieke context het voortbestaan te verzekeren van de soevereine natie waarvan het, gerekruteerd in een levée en masse, de rechtstreekse emanatie was. Door deze rol verwierf het leger een meer centrale plaats in de maatschappij dan het in de pluriforme samenlevingen van het ancien régime ooit bezeten had. ${ }^{39}$

De geschetste ontwikkelingen zijn op diverse niveaus in de muzikale sfeer aantoonbaar. ${ }^{40} \mathrm{Op}$ de muziektaal zelf drukte het militaire reeds in vele vormen zijn stempel. De Franse revolutie had, vanuit pedagogisch opzicht, de muziek uit

Academie (1859 en 1868); zie François-Joseph Fétis en het muziekleven van zijn tijd, 68-69. Over de inschakeling van de Klasse voor schone kunsten in de natievorming, zie J. Janssens, De Belgische natie viert. De Belgische nationale feesten 1830-1914 (Leuven, 2001) 34-39.

37 De tekst van Fétis' plan is op zich reeds een toonbeeld van systematiek en organisatie. In de rigide structuur van het document springt vooral het consequent vasthouden aan drieledige indelingen in het oog.

38 Michel Foucault zag de figuur van Napoleon 'au point de jonction de l'exercice monarchique et rituel de la souveraineté et de l'exercice hiérarchique et permanent de la discipline'; zie M. Foucault, Surveiller et punir. Naissance de la prison ([Parijs], 1975) 219.

39 C. Jansen, ed., Der Bürger als Soldat. Die Militarisierung europäischer Gesellschaften im langen 19. Jabrhundert: ein internationaler Vergleich (Essen, 2004).

40 P. Knevel, 'Oorgetuigen. Vijf eeuwen muziek, oorlog en vrede' en L. Sanama, 'Oorlog en strijd met 
de opera- en concertzaal naar de openlucht gebracht, waar zij in grootse evenementen het volk kon bereiken en gebruikt kon worden bij de omvorming van dit volk tot een natie van politiek en moreel bewuste citoyens. ${ }^{41}$ Muzikaal vertaalde dit zich in stoere marsritmen, waarbij de machtsverhoudingen in het instrumentarium grondig verschoven. Koper en slagwerk - de militaire trom ${ }^{42}$ - eisten hun plaats op in het hart van het muzikale gebeuren. In dit proces is opnieuw de muziek van Beethoven een mijlpaal. Naast het programmatische Wellingtons Sieg zijn er de symfonieën, met de derde en vijfde als uitschieters, waar het revolutionaire vrijheidspathos in een strijdvaardig, militair klankidioom naar buiten treedt. Het is geen toeval dat de uitvoeringen van deze symfonieën in een krant als L'Indépendant besprekingen uitlokten die bol stonden van de militaire metaforiek. Het orkest wordt er beschreven als een leger in slagorde met de diverse instrumentensecties als even zovele regimenten, en de eigenlijke uitvoering als een veldslag met de dirigent in de rol van alziend generaal. ${ }^{43}$

Niet minder anwezig was het militaire element in de opera. Ook daar manifesteerde zich deze explosie van martiale ritmen, schetterend koper en tromgeroffel. Op het toneel sloot daar een verhaal bij aan dat in vele gevallen rond de oorlog zelf draaide. Als dat niet het geval was, maakten officieren en soldaten op zijn minst in één of meerdere hoofd- en bijrollen hun opwachting. De opera kleurt pas ten volle militair vanaf het moment dat men het publiek in het beeld betrekt. In de Brusselse Muntschouwburg genoten militairen gunstige voorwaarden. Door de schittering van hun uniformen droegen zij in niet geringe mate bij tot de glans die de opera als society-gebeuren omgaf. ${ }^{44}$

muziek begeleid...', in: P. Knevel, M. van der Burgh, ed., Muziek, oorlog en vrede. Muzikaal commentaar op vijf eeuwen oorlog (Bussum, Delft, 2001) 19-38 en 102-109.

41 J. H. Johnson, Listening in Paris. A cultural history (Berkeley, etc., 1995) 97-154; B. Brévan, Les changements de la vie musicale parisienne de 1774 à 1799 (Parijs, 1980) 21-31 en 95-109; M. Ozouf, La fête révolutionnaire, 1789-1799 (Parijs, 1976); M. Vovelle, Les métamorphoses de la fête en Provence de 1750 à 1820 (Parijs, 1976).

42 In Herfsttij der Middeleewwen ziet Huizinga de opkomst van de trom als symptomatisch voor de teloorgang van het middeleeuwse ridderideaal. Zie Knevel, 'Oorgetuigen', 20.

43 Voorbeelden zijn: M., 'Premier concert du Conservatoire', L’Indépendant (23 februari 1838); A. S., 'Deuxième concert du Conservatoire', L'Indépendant (5 maart 1840); A. S., 'Chronique musicale. Quatrième concert du Conservatoire', L'Indépendant (16 mei 1840); A. S., 'Chronique musicale', L'Indépendant (23 januari 1841).

44 In 1836 telde de Muntschouwburg 190 militaire abonnees. Zie R. van der Hoeven, Le théâtre de la Monnaie au XIXe siècle. Contraintes d'exploitation d'un théâtre lyrique, 1830-1914 (Brussel, 2000) 322-323; Idem, 'Le théâtre de la Monnaie et son public. Des émeutes de La Muette de Portici (1830) au recueillement de Parsifal (1914)', BTM, LVI (2002) 25-28. In feite ging het om de versnelling en versterking van een evolutie die ook in het Europa van voor de Franse Revolutie reeds duidelijk waarneembaar was; zie M. Haine, 'Charles-Simon Favart à la tête du Théâtre des armées du maréchal de Saxe à Bruxelles (janvier 1746 - décembre 1748)’, in: P. Vendrix, ed., Grétry 
Een meer dan oppervlakkige affiniteit met het militaire bedrijf en de militaire logica was tevens kenmerkend voor het conservatorium. Het Parijse conservatorium dat in 1792-1793 om zuiver militaire redenen was opgericht, stond nadien model voor heel Europa. Geboren in het tumult van de revolutie moest de instelling professionele musici vormen voor het leger en ter opluistering van openbare feesten. ${ }^{45}$ In Brussel droeg de strakke, hiërarchische organisatie van het conservatorium nog duidelijk de sporen van deze militaire oorsprong. Als schoolinrichting vertoonde het de typische eigenschappen van het op disciplinering gerichte foucaultiaanse panopticon. Dat vergde een systeem van permanent en sluitend toezicht met de directeur als supervisor. Een grondvoorwaarde voor het handhaven van tucht was een strikte scheiding tussen jongens- en meisjesleerlingen, waarvoor het reglement en lesrooster garant stonden. ${ }^{46} \mathrm{Het}$ conservatorium kreeg overigens regelmatig bezoek van militairen, onder meer als leden van de examencommissies voor de blaasinstrumenten. ${ }^{47}$ Voor de leerlingen van deze opleidingen vormde het leger, met zijn talrijke blaaskapellen, een belangrijke bron van werkgelegenheid. In 1846 had het leger ongeveer 800 musici in dienst, gespreid over 23 regimenten. ${ }^{48}$

Men kan daarom zonder overdrijving stellen dat het leger, alleen al qua mankracht, het eerste muzikale instituut van het land geworden was. Door de spreiding over het gehele grondgebied waren de blaaskapellen van het leger, met hun welomlijnd, uniform kernrepertoire van marsen en hymnen, een van de krachtigste instrumenten voor de vorming van een nationaal gevoel. ${ }^{49}$ Aan de verregaande militarisering van de gehele muzikale ervaringswereld wijdde Edouard Fétis in 1839 een opmerkelijke beschouwing:

Nous croyons qu'en dépit de ses adversaires la musique militaire est maintenant établie de manière à n'avoir plus à craindre d'arrêts de suppression. Comment serait reçu, nous le demandons, dans une ville de garnison le régiment qui arriverait sans ce moyen actif de

et l'Europe de l'opéra-comique (Luik, 1992) 281-330; P. Gülcke, 'Dirigieren', MGG. Sachteil, II (Kassel, 1995) 1263.

45 C. Pierre, B. Sarrette et les origines du conservatoire national de musique et de déclamation (Parijs, 1895); Brévan, Les changements, 146-160.

46 Reglement, goedgekeurd bij Koninklijk Besluit van 26 augustus 1832 - SAB/OO I/95; lesrooster van 26 juni 1833 - ARA/Cons. 10.

47 Zie bijvoorbeeld 'Concours du Conservatoire', L'Indépendance Belge (1 augustus 1845).

48 E. Fétis, 'Projet d'un gymnase de musique militaire', L'Indépendance Belge (29 november 1846); E. Baeck, 'De expansie van de militaire muziek', in: Grijp, ed., Een muziekgeschiedenis, 386-391' (met literatuuroverzicht); C. Philippon, 'Les musiques militaires', in: Wangermée, Mercier, ed., La musique, II, 261-268; Idem, 'De militaire kapellen onder Leopold I', in: H. Balthazar, J. Stengers, ed., Dynastie en cultuur in België (Antwerpen, 1990) 273-278.

49 E. Hobsbawm, Nations and nationalism since 1780. Programme, myth, reality (Cambridge, 1992) 81; vergelijk J. Stengers, E. Gubin, Histoire du sentiment national en Belgique des origines à 1918, II, Le grand siècle de la nationalité belge. De 1830 à 1918 (Brussel, 2002) 27-29. 
séduction? Comment ses officiers oseraient-ils se présenter devant les belles dames du lieu s'ils n'avaient pas de corps de musique à faire jouer le dimanche sur la place publique après la messe, le soir au moment de la retraite, en hiver aux bals de la redoute et lorsqu'il y a lieu, dans l'orchestre du théâtre! Nous ne voulons humilier personne et les tambours ont toutes sortes de droits à notre estime, mais les tambours ne remplacent pas plus la musique d'harmonie qu'un feu de charbon de terre ne tient lieu du soleil de juin. Enfin pour nous servir d'une expression qu'on a trop employée pour que le sens n'en soit point parfaitement déterminé, nous dirons que les musique militaires sont passées dans nos moeurs. ${ }^{50}$

In een stad als Brussel, die verschillende garnizoenen huisvestte, ging de conclusie van Edouard Fétis zeker op. Door de drukke militaire bedrijvigheid in en rond de stad groeiden de trompetsignalen, het tromgeroffel en de marsmuziek uit tot een sonore werkelijkheid met een graad van vertrouwdheid die in het verleden slechts het klokgelui van de kerken te beurt gevallen was. Bovendien waren de activiteiten van de militaire kapellen nauw verweven met het civiele publieke leven. De militaire kapellen waren een wezenlijk onderdeel van de liefdadigheidsconcerten, één van de pijlers van de Brusselse concertagenda, en in de zomermaanden vormde de kiosk in het Park de uitgelezen omlijsting van talrijke openluchtconcerten. ${ }^{51}$

Haar apotheose beleefde de militaire muziekuitvoering op grote nationale feesten. ${ }^{52}$ Het militaire muziekfestival, dat bij de herdenking van de Belgische Revolutie op 26 september 1833430 musici op het Koningsplein samenbracht, zette de toon. De musici gaven het beste van zichzelf in een massaconcert dat door François-Joseph Fétis, voor zover dat mogelijk was, in goede banen geleid werd. ${ }^{53}$ Het festival van 1833 was het eerste in een reeks groots opgezette muziekfestivals die een wezenlijk bestanddeel gingen uitmaken van de viering van de Septemberfeesten. Deze festivals waren geen exclusieve aangelegenheid van militaire muziekkapellen, maar de deelnemende civiele muziekgezelschappen waren wel volledig naar het militaire voorbeeld gemodelleerd. De militaire logica spreekt verder uit het feit dat de festivals meestal de vorm aannamen van fel bevochten wedstrijden. ${ }^{54}$ Er was zelfs een speciale prijs voor het mooiste uniform ('prix de tenue'). ${ }^{55}$

50 E. Fétis, 'Les musiques militaires', L'Indépendant (28 maart 1839).

51 Zie de evenementen van de Société royale de Philanthropie de Bruxelles, in: Jaarverslagen van de vereniging, 1844-1868 (Stadsarchief Brussel).

52 Janssens, De Belgische natie viert, 1-22 en 30-39.

53 F. Pieters, Van trompetsignaal tot muziekkapel. Anderbalve eeuw militaire muziek in België (Kortrijk, 1981) 39-44.

54 De wedstrijden op de Septemberfeesten stonden open voor blaasensembles en/of mannenkoren. Ook de koren spiegelden zich aan het militaire voorbeeld. Zie E. Fétis, 'Chronique musicale.Concours de musique d'harmonie - Concours de chant d'ensemble', L'Indépendant (1 oktober 1841).

55 Ibidem; zie verder diverse documenten met betrekking tot de wedstrijden voor harmonieensembles die in 1827, 1830, 1835 en 1841 te Brussel georganiseerd werden - SAB/00 I/116. 
Uit de opzet van deze festivals spreekt een opmerkelijke fascinatie voor het naakte, massieve getal, wat niet los kan gezien worden van de veranderingen die in de wijze van oorlogvoering waren opgetreden. Al in de achttiende eeuw, maar de beslissende stoot kwam tijdens de revolutionaire en napoleontische oorlogen, was deze een zaak geworden van gedrilde en steeds uniformer ogende massalegers. Het is in deze context dat het fenomeen van muziekuitvoeringen met honderden uitvoerders voor een nog veel talrijker publiek geplaatst moet worden. Dergelijke manifestaties waren slechts te realiseren in de openlucht. Toen Valentin Bender, chef-dirigent van de Gidsen, op 25 september 1848 een 'concert populaire' dirigeerde op de Grote Markt, schatte de verslaggever in L'Indépendance Belge het aantal toehoorders op ongeveer 25.000. ${ }^{56}$ Allicht was dit een wat voortvarende raming, maar ze verraadt op zijn minst een mentaliteit, een hang naar duizelingwekkende getallen, een obsessie met het kwantitatieve.

In het verlengde van deze manifestaties in de openlucht lagen de vieringen in de Augustijnertempel (Temple des Augustins). De kerk van de Augustijnen, die niet meer als kerk gebruikt werd (en inmiddels gesloopt is) had van de Belgische regering in 1834 een nieuwe bestemming gekregen en fungeerde vanaf dat moment als cultusplaats van de natie. ${ }^{57}$ Dat de keuze op een kerkgebouw viel, was denkelijk geen toeval. Op de religieuze dimensie van het nationalisme - de religion civile van de negentiende eeuw - is reeds meermaals gewezen en de benaming temple is in dit opzicht veelzeggend. Het kerkgebouw in kwestie was een barokke constructie van monumentale afmetingen en daarom volkomen toegesneden op massaal bezochte nationale evenementen. François-Joseph Fétis wijdde de nationale tempel op 26 september 1834 muzikaal in. Voor een publiek van ruim drieduizend toehoorders dirigeerde hij een monsterapparaat van driehonderd musici en het dubbele aantal koorzangers. ${ }^{58}$

Het was niet alleen voor de viering van de Septemberfeesten dat de Augustijnertempel volstroomde. Naast talrijke liefdadigheidsconcerten die er gegeven werden, deed de tempel onder meer dienst bij de prijsuitreikingen van het conservatorium. Opnieuw ging het om muzikaal opgeluisterde plechtigheden, groots van opzet, met op de ereplaatsen prominenten uit de regering, het stadsbestuur, de diplomatie, tot het vorstenpaar toe. Men kan zich licht voorstellen in welke mate deze plechtigheden ertoe bijdroegen de prijswinnaars aan de natie te binden. ${ }^{59}$ De leerlingen van het conservatorium waren van bescheiden komaf en dat maakte hen des te ontvankelijker voor de indrukken die

56 'Concert populaire', L' Indépendance Belge (26 september 1848).

57 De Augustijnertempel was gelegen aan het huidige Brouckèreplein. Over het gebouw, zie Janssens, $D e$ Belgische natie viert, 36 en 42; G. Becquart-Robyns, 'De Augustijnertempel' en P. Becquart, 'De Augustijnertempel', in: François-Joseph Fétis en het muziekleven van zijn tijd, 45 en 65-66.

58 Janssens, De Belgische natie viert, 31-32. Janssens baseert zich voor de cijfers op een bericht in L'Indépendant van 28-29 september 1834. G. Becquart-Robyns houdt het evenwel op een totaal van 600 zangers en instrumentalisten, maar vermeldt geen bron; zie Becquart-Robyns, 'De Augustijnertempel', 45. Het massale karakter van het evenement staat hoe dan ook buiten kijf. 
uitgingen van de gezwollen taal. ${ }^{60}$ In de ruimte van de tempel, vol nationale symboliek, werd op deze jonge mensen een dringend beroep gedaan om zich als muzikale soldaten aan de dienst van de natie te wijden. Dit roepingsdiscours is tevens het uitgangspunt van het monumentale doek La Belgique couronnant ses enfants illustres van Henri de Caisne (1799-1852), dat centraal in de tempel opgesteld stond. ${ }^{61}$

\section{Obstakels}

De natievormende werking van muzikale uitingen die afgestemd waren op of in ieder geval doordrongen tot alle sociale geledingen van de bevolking, zoals de militaire muziekuitvoeringen of de nationale muziekfestivals, moet zeer reëel geweest zijn, al blijft het onmogelijk dit enigszins adequaat te meten. In elk geval was de Belgische overheid zich bewust van de mogelijkheden die de muziek voor het natieproject in zich droeg, en ze heeft die dienovereenkomstig gebruikt. Daarnaast was er de muziekuitvoering die deel uitmaakte van het cultuur- en societyleven van de sociale bovenlagen. Dit speelde zich af in het muziektheater en de concertzaal, alsook in de besloten ruimten van salon of huiskamer.

Wat de muziekcultuur als onderdeel van een highbrow culture betreft, worstelde het land in de bestudeerde periode met structurele problemen. In het jonge België waren de politieke en economische elites buitengewoon nauw met elkaar verstrengeld, wat het land en Brussel in het bijzonder zowat het aanzien gaf van een ambitieus economisch project. De hoofdrolspeler op het financieeleconomische terrein, de Société Générale, profileerde zich als een vierde staatsmacht en haar vertegenwoordigers werden met de bij die rol passende egards behandeld. ${ }^{62}$ Muziek kon echter niet gedijen in een klimaat waarin een eng

59 Zie onder andere 'Distribution des prix aux élèves du Conservatoire', L'Indépendant (16 juni 1841); 'Bruxelles', L'Indépendant (28 februari 1842).

60 Bij gebrek aan bronnen zijn over het sociale profiel van de leerlingen in het conservatorium geen nauwkeurige uitspraken te doen. Dat de meeste leerlingen uit bescheiden middens afkomstig waren, blijkt echter afdoende uit twee episoden (1833 en 1844) in de financiële geschiedenis van de instelling. Zie documenten in SAB/OO I/95.

61 Op het schilderij van Henri de Caisne waren 65 voorbeeldige Belgen te zien, van Karel de Grote tot prins Charles-Joseph de Ligne, onder wie ook een vierkoppige muzikale vertegenwoordiging (Josquin des Prez, Orlandus Lassus, André-Ernest-Modeste Grétry, François-Joseph Gossec). Over het genre, zie J. Tollebeek, T. Verschaffel, “A Profitable Company'. Het pantheon als historisch genre in het negentiende-eeuwse België', Bijdragen en mededelingen betreffende de geschiedenis der Nederlanden (BMGN), CXV (2000) 223-243, in het bijzonder 226-227; J. Ogonovsky, La peinture monumentale d'histoire dans les édifices civils en Belgique (1830-1914) (Brussel, 1999) in het bijzonder 299-301. Zie voor de patriottische aankleding van de Augustijnertempel: E. Fétis, 'Chronique musicale. ...Le local des Augustins ...', L'Indépendant (5 maart 1842); Idem, 'Concours de chant d'ensemble ... dans le temple des Augustins ...', L'Indépendance Belge (26-27 september 1845).

${ }^{62}$ Witte, 'De constructie van België, 1828-1847', 157-162; Idem, 'Centrumvorming in België. De rol 
begrepen utilitarisme of zelfs economisme de geesten beheerste. ${ }^{63}$ Edouard Gregoir, die tijdens het bewind van Leopold II als geen ander de loftrompet stak over het muzikale België en daarom niet van gebrek aan patriottisme verdacht kan worden ${ }^{64}$, haalt in zijn boek L'art musical en Belgique een interventie aan van Constant d'Hoffschmidt, gehouden op 10 april 1832 in de Kamer, kort na de oprichting van de conservatoria in Brussel en Luik. De volksvertegenwoordiger uit Luxemburg stak daarin een vurig pleidooi af tegen het afvloeien van belastinggeld naar beide instellingen, wat hij afdeed als 'un véritable abus de pouvoir.' '[I]l me parait que les secours doivent être volontiers; mais pour y faire contribuer les autres, jamais,' zo besloot hij zijn betoog. Waarop Gregoir, schrijvend in 1879, er haastig aan toevoegde: 'On le voit, le goût artistique, à cette époque, n’était pas aussi élevé que de nos jours. ${ }^{65}$

De Muntschouwburg, op muzikaal vlak toch hét visitekaartje van de hoofdstad, heeft in de eerste decennia na de Belgische onafhankelijkheid geen frank subsidie uit de schatkist genoten. ${ }^{66}$ Vooral de katholieke vertegenwoordigers wilden daar niet van weten, omdat zij de opera gelijkstelden met stadslucht en navenante zeden. ${ }^{67}$ Voor het Brusselse conservatorium bleef de financiële situatie zoals zij had bestaan onder Willem I aanvankelijk ongewijzigd, maar de centrale overheid dreef haar inspanningen spoedig op. ${ }^{68}$ Anders was het

van Brussel tijdens de stichtingsfase van de Belgische staat (1830-1840)', BMGN, CI (1986) 601629, in het bijzonder 613-618, 624-629.

63 Cijfers met betrekking tot de overheidsuitgaven in het domein van de kunsten zijn te vinden in V. Montens, 'Finances publiques et art en Belgique (1830-1940)', in: G. Kurgan-van Hentenryk, V. Montens, ed., L'argent des arts. La politique artistique des pouvoirs publics en Belgique de 1830 à 1940 (Brussel, 2001) 18 en 20-21.

64 Illustratief is de openingszin in zijn encyclopedie van Belgische musici: 'La Belgique est sans contredit le pays qui, relativement à sa population, a produit le plus grand nombre de virtuoses et de musiciens distingués'; zie E. G. J. Gregoir, Les artistes-musiciens belges au XVIIIe et au XIXe siècle (Brussel, etc., 1885) i.

65 E. G. J. Gregoir, L'art musical en Belgique sous les règnes de Léopold Ir E Léopold II, rois des Belges (Brussel, etc., 1879) 69. Zie brief van Vilain XIIII aan Ch. le Hon, 28 april 1833 - ARA/ Cons. 10. Positievere geluiden in het parlement jegens de schone kunsten tekende Valérie Montens op. Zie Montens, 'Finances publiques', 13-14.

66 R. van der Hoeven, 'Monnaie et deniers publics. Les subventions publiques et le théâtre royal de la Monnaie (1830-1914)', in: Kurgan-van Hentenryk, Montens, ed., L'argent des arts, 113-130.

67 E. Robin, 'Théâtre', L'Indépendance Belge (30 maart 1840). Volgens Els Witte waren de andere grote steden zich nauwelijks bewust van de noodzaak voor het land om over een belangrijke hoofdstad te beschikken en waren er tevens gevoelens van naijver in het spel. Zie E. Witte, 'L'élection communale du 31 mai 1838 à Bruxelles. La capitale et le gouvernement en conflit', Cahiers bruxellois, XII (1967) 232

68 Aanvankelijk subsidieerden regering en stad het conservatorium elk voor een bedrag van 8.465 frank, wat overeenstemde met het bedrag van 4.000 florijnen dat zij onder Willem I hadden betaald voor de Koninklijke Muziekschool. De regering dreef de subsidiëring gestaag op. In 1850 was het bedrag reeds 
gesteld met de stad Brussel die zich weinig bereid toonde in de instelling te investeren. Schreef François-Joseph Fétis de regering nog 'vues généreuses' toe, het stadsbestuur verweet hij zijn 'habituelle incurie. ${ }^{69}$ Omdat de stad de verantwoordelijkheid voor het gebouw op zich genomen had, plaatste haar stilzitten de directeur van het conservatorium voor grote problemen. ${ }^{70}$ Bovendien moest de instelling het zien te redden zonder eigen concertzaal, wat Fétis ertoe dwong voor zijn publieke concerten telkens weer aan te kloppen bij de particuliere concertverenigingen in de stad. ${ }^{71}$ Het zou echter een vertekend beeld geven de houding van het Brusselse stadsbestuur af te doen als botte onwil of complete onverschilligheid voor het culturele gebeuren. De Belgische Revolutie van 1830 had de stad financieel ontredderd en tot 1842, het jaar waarin een vergelijk getroffen werd met de centrale overheid, leefde de stad op de rand van het bankroet. Ook nadien bleef de financiële toestand van de stad nog lange tijd verre van rooskleurig. ${ }^{72}$

Toch was er meer aan de hand dan financiële onmacht. In zijn muziekkronieken beklaagde Edouard Fétis zich meermaals over de lauwheid van het Brusselse publiek voor het muziekleven in de stad en hij zocht daarvoor een verklaring in het nationale karakter. 'Nous sommes un peuple calculateur et avons les qualités aussi bien que les défauts de notre caractère,' schreef hij in 1840. De som die de Brusselaar voor muzikale ontspanning overhad, was welomlijnd en werd derhalve niet overschreden. ${ }^{73}$ In zijn uitweidingen over het publiek schemert iets door van het parvenuachtige karakter dat een niet gering deel van

opgeklommen tot 45.000 frank.Zie tabel van uitgaven en inkomsten, 1832/1833 - ARA/Cons. 10; Exposé de la situation du Royaume. Période décennale de 1841-1850, publié par le ministre de l'Intérieur (Brussel, 1852) 197.

69 Gazette musicale de la Belgique (5 november 1833); geciteerd in Vanhulst, 'Le Conservatoire royal', 209.

70 Ibidem, 209-210. De gebrekkige behuizing drukte Fétis, die Parijs gewend was, in 1833 meteen met de neus op de feiten. Nog hetzelfde jaar dreigde Fétis met ontslag, indien het stadsbestuur niet spoedig verandering in de toestand bracht.Zie documenten in ARA/Cons. 10.

71 Het feit werd in L'Indépendant meermaals een nationale schande genoemd; zie onder andere 'Chronique musicale de l'Indépendant - Concerts ...', L'Indépendant (3 maart1837); A., 'Troisièmeconcert du Conservatoire', L'Indépendance Belge (6 maart 1845). De particuliere concertverenigingen speelden in het Brusselse society-leven een belangrijke rol. Zie Vanhulst, 'Orchestres et concerts', 45-48; R. Wangermée, 'Les concerts', in: Closson, Van den Borren, ed., La musique en Belgique, 386. A. Glauden, Société Royale 'La GrandeHarmonie', 1811-1911 (Brussel, 1911).Vergelijk W. Weber, Music and the middle class. The social structure of concert life in London, Paris and Vienna (Londen, 1975) in het bijzonder 30-52.

72 L. Richald, Les finances communales en Belgique (Brussel, s. a.) 507-520; E. Witte, 'L'élection communale', 224 vlg.; vergelijk C. Loir, 'La politique muséale du jeune Etat belge. L'achat des collections artistiques de la Ville de Bruxelles', in: Kurgan-van Hentenryk, Montens, ed., L'argent des arts, 43-61.

73 E. Fétis, 'Chronique musicale. Théâtre Royal - Concerts', L'Indépendant (4 april 1840). 
de Brusselse gegoede stand kenmerkte. De snelle economische ontwikkeling van het land, gecombineerd met de vermogensverschuivingen in de Franse periode, had een bemiddelde klasse doen ontstaan, waarvan de leden hun verworven status in een aangemeten levensstijl zichtbaar wensten te maken. Een bezoek aan de opera of het bijwonen van een concert werd vooral ervaren als passend in een habitus van beschaafd en, meer nog, behoorlijk gedrag, zonder dat de muziek om zichzelf gezocht of gewaardeerd werd. Dit was eveneens het geval in andere steden en hoofdsteden, en het hoefde de ontwikkeling van een muziekcultuur niet noodzakelijk in de weg te staan, zolang er in de betrokken samenleving maar een groep aan te wijzen viel die drager was van een culturele traditie met een zekere historische diepgang. In Brussel, waarvan het belang als politiek en financieel-economisch centrum snel toenam, ontbrak deze laag nagenoeg volledig. Er was geen Brussels equivalent van het Duitse Bildungsbürgertum of het cultureel-literaire leven in een aantal Parijse salons. ${ }^{74}$

Tegelijk kampte het Brusselse opera- en concertpubliek met een vorm van onzekerheid, die goeddeels voortvloeide uit de complexe verhouding van de stad tot Parijs. In de tweede helft van de achttiende eeuw was het verfransingsproces in de Oostenrijkse Nederlanden goed op gang gekomen. Zich toespitsend op Brussel had Verlooy in zijn Verhandeling op d'Onacht der moederlyke Tael in de Nederlanden uit 1788 reeds vastgesteld dat 'al wie iet wilt wezen' in de samenleving zich het Frans en de Franse cultuur eigen probeerde te maken. ${ }^{75}$ Toch betekende de systematische politiek van assimilatie die de Fransen na de annexatie in 1795 gingen voeren, een kwalitatieve omslag in het hele proces, niet in het minst omdat de taalpolitiek nu expliciet werd ingezet als onderdeel in een modern project van natievorming, dat gedragen moest worden door het als soeverein gedachte volk. ${ }^{76}$

74 J. Kruithof, 'De samenstelling der Brusselse bevolking in 1842. Proeve tot opbouw der sociale stratifikatie', Tijdschrift voor sociale wetenschappen, III (1956) 159-221; Idem, 'De sociale samenstelling van de bevolking te Antwerpen, Brussel, Gent en Luik in 1846-1847', Handelingen der Maatschappij van geschiedenis en oudheidkunde te Gent, XI (1957) 197-235; S. de Schaepdrijver, Elites for the capital?Foreign migration to mid-nineteenth-century Brussels (Amsterdam, 1990). Zie ook H. Pirenne, Histoire de Belgique, VII, De la révolution de 1830 à la guerre de 1914 (Brussel, 1932) 251-270, in het bijzonder 259.

75 J. B. C. Verlooy, Verhandeling op d' Onacht der moederlyke Tael in de Nederlanden, J. Smeyers, J. van den Broeck, ed. (Den Haag, 1979) 105-106.

76 Hierin verschilde de taalpolitiek van de Fransen van precedenten uit het ancien régime. Zo had bijvoorbeeld Jozef II geijverd voor de verduitsing van de Habsburgse kroongebieden. De keizer, gevormd in de geest van het Duitse cameralisme, wilde in de eerste plaats de efficiëntie van het staatsapparaat en de administratie verbeteren. De taal werd vanuit deze doelstelling slechts instrumenteel, in de zin van administratief-technisch, benaderd. Zie T. C. W. Blanning, Joseph II (Londen, 1994) 70-72. 
Dat die politiek vruchten afwierp, ondervond Willem I, toen hij na 1815 slechts doodgeboren pogingen kon ondernemen om het Nederlands in de zuidelijke provincies van zijn koninkrijk als landstaal in ere te herstellen. ${ }^{77} \mathrm{De}$ Belgische Revolutie van 1830 werd dan ook gedragen door een sociale laag die cultureel volledig op Frankrijk gericht was. 'La Belgique de 1830 était francophile, avec ardeur,' aldus de kernachtige formulering van Jean Stengers. ${ }^{78}$ Naast Franse vlaggen, was de Marseillaise een van de ingrediënten die mee de stemming bepaalden van de revolutiedagen, en later, bij de herdenking van de Revolutie op de nationale feesten, galmde de Franse hymne even luid als de Brabançonne. ${ }^{79}$ In dit licht bezien was het begrijpelijk dat de idee van een onafhankelijk, zelfstandig België in Frankrijk de wenkbrauwen deed fronsen. Vanuit Frans perspectief leek een Belgische nationale cultuur, losgesneden van het Franse moederland, moeilijk te concipiëren en konden pogingen in die zin hoogstens uitdraaien op iets gebrekkigs. 'N'y-a-t-il quelque chose de dérisoire d'appeler la Belgique une nation?' lezen we in de Dictionnaire politique van Garnier-Pagès uit 1843 en de vraag werd in volle ernst gesteld. ${ }^{80}$

Dit alles maakte de Belgische natievorming als cultuurproject tot een problematisch gegeven. In feite zag het nieuwe regime zich geconfronteerd met een onmogelijke situatie, een nauwelijks te ontwarren tegenspraak. België zat ingeklemd tussen enerzijds de Franse cultuur met haar universalistische pretenties, en anderzijds de dringende noodzaak om het land een nationale identiteit te geven of, zo die al bestond, deze te consolideren. De Franse cultuur stond in haar kosmopolitische gerichtheid inderdaad open voor vreemde invloeden. Maar tezelfdertijd werd het Frans gezien als de bevoorrechte of zelfs

77 Met name in Brussel was de verfransing onomkeerbaar. Pieter van Gobbelschroy had er in 1826 bij de bestuurscommissie aanvankelijk op aangedrongen in het reglement van de Koninklijke Muziekschool een bepaling op te nemen die kennis van het Frans én het Nederlands als toelatingseis stelde voor de kandidaat-leerlingen. De commissie moest er ook op toezien dat de leraars het Nederlands machtig waren. In het reglement, dat uiteindelijk op 16 januari 1827 door van Gobbelschroy werd goedgekeurd, was van enige rigiditeit inzake het taalgebruik evenwel geen sprake meer. Artikel 20 schreef voor dat de aspiranten de beide talen moesten kennen 'autant que possible', terwijl de talenkennis van de leraars blauwblauw gelaten werd. Zie brief van Gobbelschroy aan bestuurscommissie, 25 november 1826; reglement van 16 januari 1827 - SAB/OO I/95.

78 J. Stengers, Histoire du sentiment national en Belgique des origines à 1918, I, Les racines de la Belgique (Brussel, 2000) 215.

79 Zie Gregoir, L'art musical, 16 en 19; Pieters, Van trompetsignaal tot muziekkapel, 42.

80 E. Regnault, 'Nation', Dictionnaire politique. Encyclopédie du langage et de la science politiques (Garnier-Pagès, inl.; Parijs, 1843) 625; geciteerd in Hobsbawm, Nations and nationalism, 30. JeanBaptiste Nothomb, Belgisch 'natiebouwer' van het eerste uur, schreef in 1871: 'Dans ma carrière déjà longue, je n'ai rencontré que deux Français acceptant l'indépendance de la Belgique, LouisPhilippe et Guizot'; geciteerd in J. Stengers, 'La Belgique de 1830, une 'nationalité de convention'?' in: H. Hasquin, ed., Histoire et historiens depuis 1830 en Belgique (Brussel, 1981) 7. 
enig mogelijke drager van de kosmopolitische 'super-cultuur' die het niveau van de nationaliteiten oversteeg. Het was in overeenstemming met deze gedachtegang dat Fétis, die toch geroepen was om België muzikaal weer op de kaart te zetten, en die het in zijn Plan d'organisation ondubbelzinnig had over 'le génie des Belges pour l'art musical', zich kantte tegen de idee van nationale, in de zin van 'volkseigen' muziekscholen. Hij was er namelijk van overtuigd dat de muziek, als universele taal, moest openstaan voor diverse invloeden. Op het kruispunt van de Latijnse en Germaanse wereld had België in de ontwikkeling en verspreiding van de kosmopolitische muziekcultuur zelfs een bijzondere roeping. ${ }^{81}$ Daarbij kwam het punt van het taalgebruik amper ter sprake. Kosmopolitisme en de Franse taal werden als Siamese tweelingen ervaren.

Met betrekking tot de situatie in België en zijn hoofdstad is het echter zeer de vraag of de adoratie van de Franse cultuur, los van het concrete geval Fétis, in het algemeen werd ingegeven door een bewuste kosmopolitische gezindheid. Uit de neiging om de Franse cultuur met dé cultuur tout court gelijk te stellen, sprak veeleer het verpletterende overwicht van Parijs als cultuurmetropool. Brussel had in de Franse tijd een geweldig statusverlies geleden, waarna de stad, meer nog dan in de Oostenrijkse tijd, tegenover Parijs in een marginale positie was gebleven. Omdat het Nederlands in Vlaanderen in een lamentabele toestand verkeerde in feite ging het om een verzameling van dialecten -, ondervond het Frans in de eerste decennia na de onafhankelijkheid als cultuurtaal geen enkele concurrentie. De suprematie van het Frans maakte dat het proces van de nationale identiteitsverwerving zich in België uiteindelijk slechts kon enten op de wil van de natie om als onafhankelijke politieke gemeenschap te bestaan, verenigd rond de grondwet, de koning en de instellingen. Dit politiek-geaxeerde discours sloot niet uit dat men zich op het vlak van de cultuur in engere zin (kunsten, literatuur, wetenschappen) en op dat van de civilisatie of de beschaafde omgangsvormen kon beschouwen als deel uitmakend van de grote Franse beschavingskring.

Deze gespleten toestand van politiek-cultureel dualisme resulteerde in het domein van de muziek in een tamelijk gebrekkige imitatie van het Franse voorbeeld. De Muntschouwburg, waar het repertoire een nagenoeg perfecte afspiegeling was van wat er in de Parijse muziektheaters te beluisteren viel, met de Opéra als referentiekader, is een sprekend voorbeeld. ${ }^{82}$ Operacomponisten van eigen bodem, zoals Albert Grisar (1808-1869) of Armand Limnander (18141892) verwierven slechts toegang tot de Muntschouwburg nadat hun creaties de zegen van het Parijse publiek hadden gekregen. Belgische producties die niet eerst Parijs gepasseerd waren, bleven schaars en overleefden in de regel hun

81 J. Dewilde, 'Benoit, Peter', Nieuwe Encyclopedie van de Vlaamse Beweging (NEVB), I (Tielt, 1998) 461.

82 E. Vandenberghe, 'De lyrisch-dramatische activiteit te Brussel tijdens de 19de eeuw' en 'De te Brussel meest populaire 19de-eeuwse lyrisch-dramatische componisten en hun oeuvre', De Brabantse folklore, nr. 259 en 260 (1988) 201-211 en 275-292. 
première niet. ${ }^{83}$ Ook al bleef de bijdrage van België op muzikaal-scheppend terrein gering, het land kon zich wel beroemen op enkele virtuozen van Europees formaat. In de besproken periode staan hier de namen centraal van de violist Charles de Bériot (1802-1870) en zijn evenknie op de cello, Adrien François Servais (1807-1866). ${ }^{84} \mathrm{Zij}$ waren zelf echter, de een direct, de ander indirect, het muzikale product van het vernieuwde, op methodische leest geschoeide muziekonderricht zoals dat in de Franse hoofdstad, met het conservatorium als brandpunt, tot bloei gekomen was. Daarnaast werd de waarde van Belgische virtuozen op het Europese muzikale strijdtoneel in de eerste plaats afgemeten aan de successen die zij boekten in de Franse hoofdstad. Met trots schreef Edouard Fétis in 1847 over zijn landgenoten in Parijs:

J'éprouve une vive satisfaction à vous dire que les artistes belges ont été les lions de la saison musicale. Ceci n'est pas une illusion d'amour-propre national, c'est la simple vérité. ${ }^{85}$

Het steeds weer benadrukken hoe goed de Belgische musici het in Parijs wel niet deden, is tot op zekere hoogte symptomatisch voor de onzekerheid en verregaande culturele afhankelijkheid van het jonge België. Voor het muziekleven zijn daar tal van illustraties van te geven. De Fransman J.-A. Géraldy werd in 1836 door Fétis aangetrokken als titularis van de zangklas in het conservatorium. Met Géraldy werd overeengekomen dat hij jaarlijks slechts drie maanden - later werd dit een half jaar - in Brussel aanwezig moest zijn. De rest van het jaar mocht hij zijn residentie in Parijs blijven betrekken. Naast zichtbare nadelen had deze regeling het grote voordeel, zo staat te lezen in L'Indépendant, dat Brussel de vocale ontwikkelingen in de Parijse operawereld op de voet zou kunnen volgen. Een pendelende Géraldy was, met andere woorden, 'le véritable moyen d'être toujours au courant des réformes du goût. ${ }^{86}$ Een vergelijkbaar patroon bespeurt men bij de tweejaarlijkse compositiewedstrijd die in 1840 door de regering werd ingesteld ter bevordering van de nationale toonkunst. De hele wedstrijd was een volmaakte afspiegeling van de Franse 'Prix de Rome', zoals die sinds 1803 in Parijs was ingesteld. De regering vond het zelfs nodig haar gezant in Parijs, Charles le Hon, op pad te sturen om, voor hergebruik in Brussel, de hand te leggen op het tekstmateriaal dat in voorbije jaren aan de deelnemers ter toonzetting was voorgelegd. ${ }^{87}$

83 Van der Hoeven, Le théâtre de la Monnaie, 166, 279-280 en 290-297.Zie ook 'Théâtre Royal', L'Indépendant (17 november 1838).

84 Zie B. Schwarz, 'Bériot, Charles-Auguste de', NGD, III, 358-359; H. Vanhulst, 'Bériot, CharlesAuguste de', MGG. Personenteil, II (Kassel, 1999) 1305-1309; P. Peire, 'Adrien François Servais', NGD, XXIII, 151.

85 E. Fétis, 'Paris musical - Saison de 1847. A M. le rédacteur de l'Indépendance Belge. Paris, le 20 avril', L'Indépendance Belge (25 april 1847).

86 A. S., 'Chronique musicale. Quatrième concert du Conservatoire', L'Indépendant (16 mei 1840); in dezelfde zin: 'Variétés musicales', L'Indépendant, 25 augustus 1842. 
Scherpe reacties tegen de slaafse imitatie van het Franse voorbeeld rezen in Vlaamse burgerlijke kringen. In de jaren 1840 begonnen zij zich mondiger te uiten, ook in het grondig verfranste Brussel. Hoe de vroege vertegenwoordigers van de Vlaamse ontvoogdingsstrijd het officiële muziekleven in de hoofdstad ervoeren, komt men vrij goed te weten uit de berichten in Vlaemsch België. De geschiedenis van dit eerste Nederlandstalige dagblad in Brussel was kort en bewogen - de krant overleefde haar oprichtingsjaar 1844 niet. ${ }^{88}$ Het verschijnen van Vlaemsch België viel evenwel in een periode waarin België en vooral Vlaanderen in een steeds nauwere relatie tot Duitsland kwam te staan. Op economisch gebied leidde de toenadering in september 1844 tot een handelsakkoord tussen België en de Duitse Zollverein. Niet minder beweging was er op het culturele vlak. De Muntschouwburg ontving in hetzelfde jaar een Duits gezelschap dat de Belgische hoofdstad kennis liet maken met de oorspronkelijke, niet in het Frans vertaalde versies van enkele meesterwerken uit het Duitse repertoire (Die Zauberflöte, Fidelio, Der Freischütz). ${ }^{89}$ Voor een vollediger begrip van de Brusselse muzikale realiteit zijn de daaraan gewijde kolommen in Vlaemsch België zeer verhelderend, want de omfloerste stijl die de beschouwingen over het Brusselse publiek in de gevestigde Franstalige pers kenmerkte, blijft hier achterwege.

Op 2 augustus 1844 wond Domien Sleeckx, vast medewerker van de $\mathrm{krant}^{90}$, zich behoorlijk op over de koele bespreking van Mozarts Zauberflöte in L'Indépendance Belge en L'Emancipation. Die hadden het succes van de opvoering vooral toegeschreven aan de toeloop van in Brussel verblijvende Duitsers. $^{91}$ Het ontlokte Sleeckx een giftige sneer naar zijn Franstalige medeburgers:

Dat er echter ook franskiljons waren, zal men uit het volgende geestige gesprek begrypen, dat tusschen eene dame en eenen heer met strookleurige handschoenen nevens ons werd gehouden: - Comment trouvez-vous la pièce, Madame? (Nota benè, het was de Tooverfluit.) -Une véritable bamboche! - Et la musique? - Bamboche! Wy hadden groote goesting om hun te zeggen, dat die bamboche door zekeren mynheer Mozart, was gekomponeerd

87 A. S., 'Chronique musicale. Concours du Conservatoire royal de musique - Concours pour le grand prix de composition', L'Indépendant (14 augustus 1941); zie verder A. vander Linden, 'Considérations historiques sur le 'Prix de Rome' de musique au XIXe siècle', Mededelingen van de Klasse der Schone Kunsten - Koninklijke Academie van België, LI (1969) 229-251.

88 E. de Bens, Vlaemsch België, het eerste Vlaamgezinde dagblad (Gent, 1968).

89 Het gezelschap, onder leiding van M. Remie, was in de Muntschouwburg te gast van 25 juli tot 11 augustus 1844; zie J. Isnardon, Le théâtre de la Monnaie depuis sa fondation jusqu'à nos jours (Brussel, 1890) 333-334.

90 R. Vanlandschoot, M. de Moor, 'Sleeckx, Domien', NEVB, III, 2758-2760 (met literatuuroverzicht).

91 De medewerkers van de Franstalige kranten in Brussel waren in Vlaemsch Belgiëhet voortdurende mikpunt van spot. Zo ook Edouard Fétis.Zie 'Aerdryks- en muzykkundige studien der FranschBelgen', Vlaemsch België (8-9 juli 1844). 
geworden. Wy lieten het echter, om de eenvoudige reden, dat wy vreesden ons met de grootste verwondering te hooren vragen: Mozâr! Qu'est-ce que c'est que cela? ? $^{92}$

In Vlaamsgezinde kringen sloeg de wrevel over de Franstalige dominantie in België veelal om in een onverholen ressentiment tegen de Franse cultuur zelf, waarbij Frankrijk gelijkgesteld werd met zijn hoofdstad. Op Parijs paste een reeks gemeenplaatsen die van de stad aan de Seine een moderne versie van het decadente Rome maakte, een poel van verderf die in zijn bandeloosheid het bijbelse Sodom en Gomorra naar de kroon stak. De kosmopolitische cultuur die met Parijs geassocieerd werd, kon slechts het product zijn van een schijnbeschaving en werd als krachteloos en verwijfd afgedaan. ${ }^{93}$

Even eenzijdig was de wijze waarop in Vlaemsch België de Duitse muziek en de Duitse cultuur in het algemeen de hemel in geprezen werden. De muziek van Mozart, Beethoven of Weber was alles wat de Franse muziek niet was: oorspronkelijk, krachtig, mannelijk. ${ }^{94}$ Nadat Sleeckx op 5 augustus 1844 in de Muntschouwburg een uitvoering van Beethovens Fidelio had bijgewoond, schreef hij:

Van de muziek van Fidelio, dat wy gisteren avond zagen vertoonen, kunnen wy niets zeggen; het is te grootsch, te verheven schoon, om te kunnen ontleed worden, door iemand die voelt. $^{95}$

Opmerkelijk is hoe de waardering van de Duitse muziek, naast een esthetisch, ook een uitgesproken ethisch oordeel bevat. Duitsland verschijnt er als de onbaatzuchtige Kulturnation, geroepen om Europa te vrijwaren voor de gevaren van materialisme en hedonisme die van een ongebreidelde modernisering uitgingen. ${ }^{96}$

92 D. Sleeckx, 'Kunst- en Letternieuws. De duitsche zangers op den brusselschen schouwburg', Vlaemsch België (2 augustus 1844); vgl. D. Sleeckx, 'Kunst- en Letternieuws', Vlaemsch België (8 augustus 1844).

93 Het was een Frankrijkbeeld dat, in de woorden van Herman J. Elias, 'grof eenzijdig en vervalst' was, zie H. J. Elias, Geschiedenis van de Vlaamse gedachte (4 dln.; Antwerpen, 1963-1965) II, 112; zie verder diverse bijdragenin R. de Bont, T. Verschaffel, ed., Het verderf van Parijs (Leuven, 2004).

94 Zie bijvoorbeeld 'Stemmuziek', Vlaemsch Belgie (13 september 1844) (artikel overgenomen uit de Vlaemsche Letterbode ). Zie voor het gender-aspect in het nationalistische discours over muziek: A. Fauser, 'Gendering the nations. The ideology of French discourse on music (1870-1914)', in: H. White, M. Murphy, ed., Musical constructions of nationalism. Essays on the history and ideology of European musical culture 1800-1945 (Cork, 2001) 72-103.

95 D. Sleeckx, 'De duitsche zangers op den brusselsche schouwburg, II, Freischütz', Vlaemsch België (7 augustus 1844).

96 Illustratief is het verslag van de wedstrijd die het Gentse koor der Melomanen in juli 1844 had ingericht; zie 'Kunst- en Letternieuws', Vlaemsch België (11 juli 1844). Over de germanofiele stroming in de vroege Vlaamse beweging en de plaats van het Vlaemsch-Duitsch Zangverbond daarin, zie H. von 


\section{Terugblik en witzicht}

Voor wie terugblikt in de tijd zijn de gloedvolle verslagen van het Brusselse muziekleven in Vlaemsch België gemakkelijk herkenbaar als de prille signalen die het ontwaken van een meer authentieke nationale toonkunst aankondigden. Naties zijn echter geen vaste, onwrikbare entiteiten. Peter Benoit (1834-1901), voortgekomen uit de bedding die door een dagblad als Vlaemsch België mee getrokken was, 'leerde zijn volk zingen', maar hij ging daarbij wel uit van een duurzame culturele dualiteit van België. Strevend naar een vorm van cultureel federalisme, richtte hij zich in zijn inspanningen tot muzikale volksverheffing uitsluitend tot de Vlamingen, die hij onderbracht bij de Germaanse stam, terwijl hij het leren-zingen van het zuidelijke landsgedeelte volgens dezelfde logica noodzakelijkerwijs aan een Latijnse evenknie over te laten had. ${ }^{97}$ Benoit is in zijn radicalisme een vroege exponent van de oppositionele richting, waarin de Franse culturele dominantie het Vlaamse emancipatiestreven in zijn houding tegenover de Belgische eenheidsstaat mettertijd deed evolueren. De op gang gebrachte centrifugale krachten laten de vraag open of sindsdien ooit iets tot stand gekomen is dat als een Belgische nationale muziekcultuur kan omschreven worden.

Gelezen in hun specifieke context kunnen de muziekberichten in Vlaemsch België licht werpen op de politiek-culturele machtsconstellatie in het jonge koninkrijk België. Bovendien zeggen deze teksten iets over het nationalisme dat als ideologie tot vandaag toe een van de grote determinanten in de menselijke samenleving is gebleven, en dit op mondiale schaal. Meer bepaald komen in zwart-wit de spanningen aan de oppervlakte die intrinsiek verbonden lijken met het gegeven van de natiestaat en die zowel in de schoot van de natiestaten zelf als in hun onderlinge verhouding een potentiële bron zijn van conflict. Men stelt daarbij vast hoe de ontwikkelingen in de diverse maatschappelijke sferen politiek, economie, cultuur, techniek - op elkaar inwerken en elkaar wederzijds

der Dunk, Der deutsche Vormärz und Belgien 1830/48 (Wiesbaden, 1966) 259-289 en 317-330; H.

J. Elias, Geschiedenis van de Vlaamse gedachte, II, 122-132 en 353-372, in het bijzonder 354-355;

J. Dewilde, 'Vlaemsch-Duitsch Zangverbond', NEVB, III, 3501-3502. De Vlaamse beweging kan uiteraard niet in zijn geheel met een blinde, kritiekloze germanofilie gelijkgesteld worden. Zo zou Sleeckx zelf zijn medestanders reeds in 1846, in zijn manifest 'Waer henen?', wijzen op de gevaren van een voorbarige toenadering tussen België en Duitsland; zie H. von der Dunk, Der deutsche Vormärz, 314

97 Over Peter Benoit zie J. Dewilde, 'Benoit, Peter', $N E V B$, I, 461-463 (met literatuuroverzicht). Over de plaats van Benoit in de Vlaamse muziekbeweging zie J. Dewilde, '1861. Nationalistische muziek in Vlaanderen', in: Grijp, ed., Een muziekgeschiedenis, 455-460; Idem, 'Muziek', NEVB, II, 2114-2134, in het bijzonder 2117-2123; H. Willaert, J. Dewilde, 'Het lied in ziel en mond'. 150 jaar muziekleven en Vlaamse Beweging (Tielt, 1987) 31-70. Peter Benoit, die zowel het Franse als Duitse muziekleven van binnenuit kende, heeft de tegenstelling Frans-Duits zeer scherpgesteld. Zie P. Benoit, Verhandeling over de nationale toonkunde (Antwerpen, 1875) 28 en 50. 
versterken. In de bestudeerde casus is veel aandacht besteed aan de militaire component in het Brusselse muziekleven. Dat dit muziekleven welhaast door het krijgbedrijf geïmpregneerd leek, wekt op het eerste zicht verwondering. Met zijn liberale grondwet en modern-industriële profiel was België immers zo ongeveer het zinnebeeld van de moderne, burgerlijke maatschappijordening, en in alles de tegenpool van het door de Junkers beheerste, militaristische Pruisen, waarbij beide kenmerken volgens de geijkte zienswijze in een onlosmakelijke samenhang met elkaar worden gezien. Overigens was het niet in het politiek marginale Vlaemsch België, maar wel in de liberale, met het regime vergroeide krant L'Indépendant / L'Indépendance Belge dat de militaire grondtoon zich het sterkst liet voelen. Het zijn elementen die de reflectie over het nationalisme als ideologie, de aard van de burgerlijke natiestaat en de werking van een nationaal gebonden en beleefde cultuur prikkelen.

Tenslotte roepen de gedane bevindingen vragen op met betrekking tot de muziek zelf. Meermaals kwam Beethoven ter sprake, wiens muziek, beschouwd in haar ruimere historische context, blijk geeft van een paradox. Weinig klanken kunnen een ontroering teweeg te brengen als het 'Alle Menschen werden Brüder' uit de Negende Symfonie. Waarschijnlijk heeft de roep om vrede en universele broederschap nooit indringender weerklonken. Beethoven richt zijn appèl tot de mensheid evenwel in een muziektaal die wat de ritmische structuur en het gebruikte instrumentarium betreft, van het martiale, het krijgsgewoel doordrongen is. In zijn grootse schepping laat Beethoven zich, in het spoor van de Franse Revolutie, herkennen als de muzikale incarnatie van de 'missionnaire armé', zij het in de meest gesublimeerde vorm. Juist de dubbelzinnigheid die aan zijn genie kleeft, maakt de componist tot een van de archetypische gestalten van de Europese cultuur. 


\title{
Gewetenloze kapitalisten, handige fiscalisten, strategische huisvaders of gedisciplineerde calvinisten? De Nederlandse Republiek als casestudy
}

\author{
MARJOLEIN 'T HART
}

J. Adams, The familial state. Ruling families and merchant capitalism in early modern Europe (Ithaca, New York: Cornell University Press, 2005, 250 blz., ISBN 08014 3308 8).

$\mathrm{Ph}$. S. Gorski, The disciplinary revolution. Calvinism and the rise of the state in early modern Europe (Chicago, Londen: The University of Chicago press, 2003, xvii +249 blz., ISBN 0226304833 (gebonden), ISBN 022630484 (paperback)).

L. Greenfeld, The spirit of capitalism. Nationalism and economic growth (Cambridge, Mass., Londen: Harvard University Press, 2003, xi + 541 blz., ISBN 067401239 9). J. Glete, War and the state in early modern Europe. Spain, the Dutch Republic and Sweden as fiscal-military states, 1500-1660 (Londen, New York: Routledge, 2002, viii + 277 blz., ISBN 0415 226457).

De Nederlandse Republiek blijft buitenlandse collegae boeien. $\mathrm{Na}$ de eeuwwisseling zijn in korte tijd vier Engelstalige studies verschenen die het vroegmoderne Nederland in een vergelijkend kader zetten. De auteurs gaat het niet zozeer om nieuw empirisch materiaal over de Nederlandse geschiedenis te brengen; eerder willen zij grootschalige historisch-sociologische ontwikkelingen duiden en verklaren. De Republiek is daarbij een casestudy van bijzonder belang. Elk van de hier besproken auteurs benadrukken een opmerkelijk kenmerk van het vroegmoderne Nederland: in het geval van Adams gaat het om staatsvorming en familienetwerken, Gorski bestudeert staatsvorming en religie, bij Greenfeld is het onderwerp de kapitalistische ondernemersgeest en Glete behandelt de ontwikkeling van de fiscaal-militaire staat. Dit recensieartikel zal bespreken hoe deze vier historisch-sociologen de Nederlandse Republiek zien en in hun vergelijkingen betrekken. Aan het eind zal ik kijken of deze auteurs overeenkomen in hun visie op de Republiek en in hoeverre dat een nieuwe visie is vergeleken met een twintigtal jaar geleden.

De buitenlandse belangstelling voor het vroegmoderne Nederland is uiteraard niet nieuw. In de jaren zeventig van de vorige eeuw plaatsten Fernand Braudel en Immanuel Wallerstein de Republiek prominent op de agenda. Die invloed werkt nog steeds door. ${ }^{1}$ Ook de publicaties van Jonathan Israel en van Jan de Vries en Ad van der Woude kunnen rekenen op een breed lezerspubliek. Voor de sociaal-

1 Zie bijvoorbeeld Ch. P. Kindleberger, World economic primacy, 1500-1990 (New York, Oxford, 1996) en G. Arrighi, The long twentieth century. Money, power and the origins of our times 


\title{
Gewetenloze kapitalisten, handige fiscalisten, strategische huisvaders of gedisciplineerde calvinisten? De Nederlandse Republiek als casestudy
}

\author{
MARJOLEIN 'T HART
}

J. Adams, The familial state. Ruling families and merchant capitalism in early modern Europe (Ithaca, New York: Cornell University Press, 2005, 250 blz., ISBN 08014 3308 8).

$\mathrm{Ph}$. S. Gorski, The disciplinary revolution. Calvinism and the rise of the state in early modern Europe (Chicago, Londen: The University of Chicago press, 2003, xvii +249 blz., ISBN 0226304833 (gebonden), ISBN 022630484 (paperback)).

L. Greenfeld, The spirit of capitalism. Nationalism and economic growth (Cambridge, Mass., Londen: Harvard University Press, 2003, xi + 541 blz., ISBN 067401239 9). J. Glete, War and the state in early modern Europe. Spain, the Dutch Republic and Sweden as fiscal-military states, 1500-1660 (Londen, New York: Routledge, 2002, viii + 277 blz., ISBN 0415 226457).

De Nederlandse Republiek blijft buitenlandse collegae boeien. $\mathrm{Na}$ de eeuwwisseling zijn in korte tijd vier Engelstalige studies verschenen die het vroegmoderne Nederland in een vergelijkend kader zetten. De auteurs gaat het niet zozeer om nieuw empirisch materiaal over de Nederlandse geschiedenis te brengen; eerder willen zij grootschalige historisch-sociologische ontwikkelingen duiden en verklaren. De Republiek is daarbij een casestudy van bijzonder belang. Elk van de hier besproken auteurs benadrukken een opmerkelijk kenmerk van het vroegmoderne Nederland: in het geval van Adams gaat het om staatsvorming en familienetwerken, Gorski bestudeert staatsvorming en religie, bij Greenfeld is het onderwerp de kapitalistische ondernemersgeest en Glete behandelt de ontwikkeling van de fiscaal-militaire staat. Dit recensieartikel zal bespreken hoe deze vier historisch-sociologen de Nederlandse Republiek zien en in hun vergelijkingen betrekken. Aan het eind zal ik kijken of deze auteurs overeenkomen in hun visie op de Republiek en in hoeverre dat een nieuwe visie is vergeleken met een twintigtal jaar geleden.

De buitenlandse belangstelling voor het vroegmoderne Nederland is uiteraard niet nieuw. In de jaren zeventig van de vorige eeuw plaatsten Fernand Braudel en Immanuel Wallerstein de Republiek prominent op de agenda. Die invloed werkt nog steeds door. ${ }^{1}$ Ook de publicaties van Jonathan Israel en van Jan de Vries en Ad van der Woude kunnen rekenen op een breed lezerspubliek. Voor de sociaal-

1 Zie bijvoorbeeld Ch. P. Kindleberger, World economic primacy, 1500-1990 (New York, Oxford, 1996) en G. Arrighi, The long twentieth century. Money, power and the origins of our times 